Foreword by Professor Anna Botsford Comstock . . . . . . . . . . viI

Ir.troduction $\ldots \ldots \ldots \ldots \ldots \ldots \ldots \ldots \ldots \ldots \ldots \ldots \ldots \ldots \ldots \ldots \ldots \ldots \ldots \ldots$

\title{
PART I: NATURE LORE IN CAMP
}

Chapter I.

Chapter II.

Chapter III.

Chapter IV.

Chapter V.

Chapter VI.

Chapter VII.

Chapter VIII.

Chapter IX.

Chapter X.

Chapter XI.

Chapter XII.

Chapter XIII.
Nature Leaders for Camp . . . . . . . . . . . . . I

Nature-Lore for Camp . . . . . . . . . . . . . I3

The Nature Way at Camp Chequesset........ 33

The Camp Museum. . . . . . . ........... 43

Etiquette of the Woods . . . . . . . . . . . . . 49

Religion from the Out-of-doors. . . . . . . . . . 53

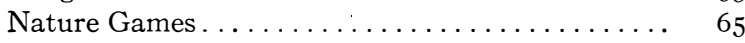

Suggestions for Nature Trails . . . . . . . . . . . 77

The Nature Guide's Dictionary . . . . . . . . . . . 99

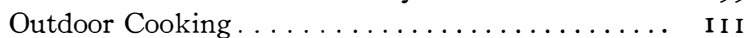

Craft out of the Environment........... I23

Common Mistakes in Nature Beliefs . . . . . . . . I I33

Timber Lines. . . . . . . . . . . . . . . I 59

\section{PART II: NATURE-STUDY IN SCHOOLS}

Chapter XIV. Chapter XV.

Chapter XVI.

Chapter XVII.

Chapter XVIII.

Chapter XIX.

Chapter XX.

Chapter XXI.

Chapter XXII.

Chapter XXIII.

Chapter XXIV.

Chapter XXV.

Chapter XXVI.

Chapter XXVII.

Chapter XXVIII.
Teacher Training in Nature-study . . . . . . . . . I69

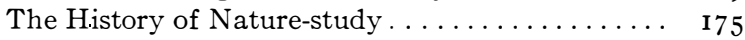

The Nature-study Club . . . . . . . . . . . . . . . 193

The Psychological Basis of Organization. . . . . . 199

Some General Principles of Teaching ......... 2 I 5

The Teaching Lesson . . . . . . . . . . . . . . 233

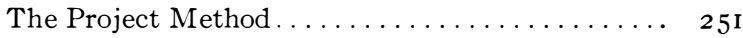

Knowing Nature Facts . . . . . . . . . . . . . . 263

Observation Tests.................. 279

Mainly Pedagogy of Seeds with some Seeds of Ped-

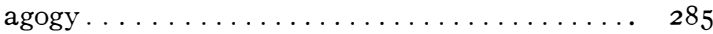

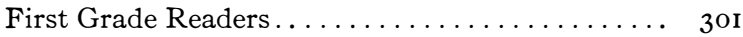

Suggestions for Arbor Day Program . . . . . . . 309

Mechanical Aids in Nature-study . . . . . . . . 323

The Use of Pictures................. 335

Nature-study by Grades. . . . . . . . . . . 339

PART III: SUGGESTIONS FOR SOME NATURE-STUDY LESSONS

Chapter XXIX.

Chapter XXX.

Chapter XXXI.

Chapter XXXII.

Chapter XXXIII.

Chapter XXXIV.

Chapter XXXV.
The Wind ...................... 353

The Rain . . . . . . . . . . . . . . . 359

The Hill. . . . . . . . . . . . . . . . 365

The River and The Valley............ 37 I

Map Study..................... 377

Ten Lessons on Our Food Supply . . . . . . . . 383

Nature Gardening................ 39 I 
Chapter XXXVI. The Potato................... 407

Chapter XXXVII. Potato Geography ................ 4 I5

Chapter XXXVIII. The Tomato................... $42 \mathrm{I}$

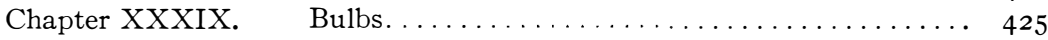

Chapter XL. Community Projects in a Sandbox......... 427

Chapter XLI. Tree Surgery and Dentistry . . . . . . . . . 433

Chapter XLII. Uses of the Forest................. 437

Chapter XLIII. Ornamentation with Plants............. 439

Chapter XLIV. $\quad$ Plant Diseases ................... 453

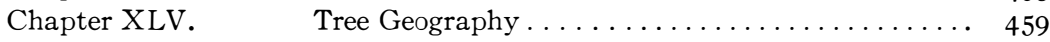

Chapter XLVI. The Locust.................... 469

Chapter XLVII. The Woodpecker................. 473

Chapter XLVIII. The Black Crowned Night Heron . . . . . . . . . 479

Chapter XLIX. The Blue Jay ................. 487

PART IV : NATURE GUIDING IN PARKS

Chapter L.

Chapter LI.

Chapter LII.

Chapter LIII.

Chajter LIV.

The Diary of A Nature Guide's Son . . . . . . . . . 493

Notes by a Yosemite Nature Guide. . . . . . . . 503

Nature-study on the Playground........... 52 I

Winter Nature-study . . . . . . . . . . . . . . 525

Bibliography . . . . . . . . . . . . . 529

\section{PUBLISHERS' ACKNOWLEDGMENTS}

I appreciate the courtesy of the publishers who have allowed me to use the following quotations and poems: Harper and Bros., poem, Friends, by John Kendrick Bangs; The Bobbs-Merrill Company, for quotations from James Whitcomb Riley as follows-from RHymes of Childhood, copyright 1890, from Green Fields and Running BRooks, copyright 1892, and other quotations; the Boston Transcript and Miss Ruth Hall for the poem To An English Sparrow by Hazel Hall; The Century Company for Blanche E. Wade's Nature Study and Teacher, and Carolyn Wells' An Apple Lesson which appeared in the St. Nicholas Magazine; Chicago Tribune for The Line O' Tyfe or Two; Henry Turner Bailey for quotation from The Children's Birthright; Henry Van Dyke for quotations on pages 53 and 322; The Science Press for quotation from the Scientific Monthly for April, 1923, page 492; The Comstock Publishing Company for various quotations from Professor Anna Botsford Comstock and Dr. L. H. Bailey; Houghton Miffin Co., Riverside Press, and Mrs. Enos Mills for Imagination Guides the Race which is in part used in Your National Parks by Enos Mills; the Oswego Normal School for the picture of Dr. Sheldon. 